\title{
Drivers of Wetland Utilisation Patterns and The Current Status of Provisioning and Cultural Services In Driefontein and Intunjambili Wetlands, Zimbabwe
}

Tatenda Musasa ( $\square$ tatendamus14@gmail.com )

Midlands State University https://orcid.org/0000-0001-9555-0774

Thomas Marambanyika

Midlands State University

\section{Research Article}

Keywords: Household's economy, horticultural activities, livelihoods, wetland ecosystem services, wetland utilization patterns

Posted Date: April 28th, 2021

DOI: https://doi.org/10.21203/rs.3.rs-407489/v1

License: (c) (i) This work is licensed under a Creative Commons Attribution 4.0 International License.

Read Full License 


\section{Abstract}

The study assesses drivers of wetland utilisation patterns and the current status of provisioning and cultural services in Driefontein and Intunjambili wetlands, Zimbabwe. A total of 280 questionnaires were administered together with semi-structured interviews conducted with key informants in the two wetlands. Qualitative data obtained through the questionnaire survey and key informant interviews were analyzed using the content analysis method. The majority of the households in Driefontein (86\%) and Intunjambili (75\%) indicated that there is no change in wetland utilisation patterns over the past decade as horticultural activities remain the predominant activity. Most households $(90 \%)$ in Intunjambili indicated that the availability of water is the major factor influencing wetland use. This was different from Driefontein where market availability for horticultural products $(66 \%)$ was the main reason for wetland use. Land use land cover (LULC) changes established through analysis of remotely sensed imagery for the years 1999, 2009 and 2019 indicate an increase in the spatial extent of the cultivated area, bare land and a decrease in the area covered by water. Results also show that the two wetlands are providing water for drinking and crop cultivation, pasture for livestock grazing and opportunities for academic incursions. Overall, the two wetlands provide essential provisioning and cultural services hence the need for wise use and proper management to prevent their degradation and possibly loss of human benefits.

\section{Introduction}

In Southern Africa, wetlands are essential since they provide key services vital to human well-being especially the poor in rural areas who largely dependent on agriculture (Adekola et al. 2008; Ndhlovu 2012; Ndiweni and Gwate 2013). Healthy wetlands provide direct and indirect benefits to communities through goods and services (Millennium Ecosystem Assessment, 2005; Mtambanengwe 2006; Turpie et al. 2010; Mandishona and Knight 2019). Their contribution to human survival has been confirmed by Millennium Ecosystem Assessment (2005), which demonstrated the intricate relationships between wetland ecosystems and human livelihoods (Millennium Ecosystem Assessment 2005; Chuma et al. 2008). Rural communities consider wetlands to be important ecosystems which should be used wisely since they obtain essential services (Adekola et al. 2008; Ndiweni and Gwate 2013).

Several biophysical and socio-economic factors determine wetland utilisation resulting in their possible degradation (Russi et al. 2013; Musasa and Marambanyika 2020). In light of the prevailing semi-arid conditions in Southern Africa, wetlands in transboundary basins provide alternative resources essential for human livelihood (Finlayson and Pollard 2009; McCartney et al. 2011). Crop cultivation has been largely driven by varying rainfall patterns which Mazvimavi (2010) and Ndiweni and Gwate (2013), described as having negative impacts on crop yields. Therefore, wetlands become the only repository of moisture during dry periods thus farmers turn to them for agriculture (Madebwe and Madebwe 2005; Mbereko et al. 2015). 
Implementation of various wetland-based food security projects through donor funding motivates wetland cultivation by rural communities (Hove and Chapungu 2013; Marambanyika and Beckedahl 2016a). In the Missavene wetland in Mozambique donors assisted local people with inputs for rain-fed agriculture by providing seeds (Finlayson and Pollard 2009). According to Hove and Chapungu (2013), in Magwenzi wetland in Chivi District, Non-Governmental Organisations (NGOs) such as Zvishavane Water Project provided key elements such as elephant pumps, fencing materials, farming inputs like inorganic fertilizers and seeds for use in wetland cultivation. Provision of these inputs therefore, resulted in local people shifting attention towards crop cultivation yet the impact of these activities has not been fully examined. The existence of donor funding has also meant over abstraction of water through artificial wells and boreholes, construction of canals which affect water distribution and retention in catchment areas (Hove and Chapungu 2013). Therefore, understanding the drivers of wetland use is imperative in determining the suitable land use types to promote in wetlands. This will undoubtedly contribute towards the attainment of Sustainable Development Goal (SDG) 14 (Life below water) and SDG 15 (Life on land), meant to promote wise use of wetlands, from a Ramsar convention perspective.

Whereas studies such as that of Sekane et al. (2011) have reported that, seniority in the age of household head increases dependency on wetland utilisation for food security. Tumusiime et al. (2018) observed that increasing age of household broadens the spectrum of resources available for wetland utilisation. Households headed by females had limited access to this fragile resource due to lower access to natural resources including wetlands (Sekane et al. 2011; Tumusiime et al. 2018). In communal areas of Zimbabwe, diversification of horticultural activities has been necessitated and sustained by the emergence of external markets (Fakarayi et al. 2015; Marambanyika and Beckedahl 2016a). In some cases, horticultural products are exchanged for maize in periods of drought through barter trade which improves the food security status.

Wetlands provide provisioning, cultural, regulatory and supporting services (Millennium Ecosystem Assessment 2005; Chiputwa et al. 2006; Ndhlovu 2012; Turpie et al. 2010; Ongoro 2017).The economic value of wetland ecosystem services far outweighs many terrestrial ecosystems (Ramsar Convention Secretariat 2018). Davidson et al. (2018) estimated global economic value of wetland goods to be US\$70 billion a year. The services delivered by wetlands globally have been arguably valued approximately US\$14 trillion annually (Ramsar Convention Secretariat 2018). Wetland ecosystems provide goods and services vital for the sustenance of livelihoods mainly through crop cultivation, livestock grazing, fruits, firewood extraction and medicine (Chiputwa et al. 2006; Finlayson and Pollard 2009; Rebelo et al. 2010; Sakane et al. 2011; Marambanyika and Beckedahl 2016b).

In terms of the order of importance, rural communities have placed great need on provisioning and cultural services which are the focus of this research as they contribute to societal well-being (Millennium Ecosystem Assessment 2005; Adekola et al. 2008). Provisioning and cultural services are essential to daily human needs in relation to a natural resource and directly influence changes in the wetland's ecological conditions (Dehnhardt et al. 2019; Musasa and Marambanyika 2020) unlike supporting and regulating services which are mainly studied from a scientific point of view (Russi et al. 2013). Therefore, 
this study assesses the drivers of wetland utilisation patterns and the current status of provisioning and cultural services in Driefontein and Intunjambili wetlands.

\section{Materials And Methods}

\section{Description of the study areas}

The study was carried in Driefontein and Intunjambili wetlands located in the Midlands and Matabeleland South province of Zimbabwe respectively. Driefontein wetland (30 $47.00^{\prime} \mathrm{E} 19^{\circ} 23.00^{\prime} \mathrm{S}$ ) is located in ward 20 Chirumanzu Rural District Council (RDC) (Figure 1) and Intunjambili wetland (28 $41^{\prime} \mathrm{E}$ and $20^{\circ} 27^{\prime} \mathrm{S}$ ) in ward 15 Matobo RDC (Figure 1).

\section{Figure 1: Map showing the location of the wetlands studied}

The wetlands were selected based on the hydro-geomorphic characteristics, tenure, land use type and natural farming regions in Zimbabwe. Driefontein wetland falls under the Zambezi geomorphic province of Zimbabwe at an altitude of 1500 meters. Intunjambili wetland is under the Limpopo geomorphic province of Zimbabwe at an altitude of 1350 meters above sea level.

Zimbabwe is divided into seven natural farming regions based on precipitation (Zimbabwe National GeoSpatial and Space Agency 2020). Driefontein wetland is in region III receiving rainfall between $650-800$ $\mathrm{mm}$ a situation that is likely to motivate local communities to practice crop cultivation. In contrast, Intunjambili wetland is in Zimbabwe's natural farming region IV and receives rainfall between 450-650 mm (Finlayson and Pollard 2009; Ndhlovu 2009; Zimbabwe National Geo-Spatial and Space Agency 2020). Changes in annual rainfall totals and the increased frequency of droughts is likely to influence changes in wetland use type and the status of the existing ecosystem services.

In terms of climate, the Intunjambili wetland has a short wet season and a long dry season characterised by high temperatures (Chiputwa et al. 2006; Finlayson and Pollard 2009; Ndiweni and Gwate 2013). Temperatures reach 40 degrees Celsius in summer and drop to zero in winter (Chiputwa et al., 2006). In the Driefontein wetland mean annual temperatures range from $12{ }^{\circ} \mathrm{C}$ during winter to $32^{\circ} \mathrm{C}$ in summer, with frost being common in winter (Mugandani et al. 2012). As a result of climate variability, the sustainability of dry land crop cultivation is compromised.

Human population has been growing in households surrounding the wetlands and the majority are poor and vulnerable. Ward 20 of Chirumanzu district, where Driefontein wetland is located, has a total of 8303 people with females constituting $51 \%$ (4 174) of the entire population. Human densities in the Driefontein wetland have increased due to the Fast-Track Land Reform Programme (FTLRP) which commenced in 2000. Ward 15 of Matobo district, where Intunjambili wetland is located, has a population size of 5089 people which shows an increase of 1.3\% from 2002 (Zimbabwe National Statistics Agency 2013).

\section{Field data collection and analysis}


Field surveys were carried out between May and July 2020 using a questionnaire and semi-structured interviews to collect data on wetland utilization patterns. The sample size for the household questionnaire survey was calculated using Raosoft sample size calculator at $95 \%$ Confidence level, with an error margin of $5 \%$. Only villages with households that utilize wetlands and or aware of wetland history due to their proximity formed the sampling frame. The population sizes for villages with households targeted in the Driefontein and Intunjambili wetlands are 270 and 175 respectively (Table 1). Therefore, using the Raosoft software, the recommended sample size for the survey was 159 for Driefontein and 121 for Intunjambili wetland respectively. As a result, a total of 280 questionnaires were randomly distributed to household heads in the selected villages using random number tables based on the established community registers (Table 1 ).

\section{Table 1: Sampling sites and sample size in relation to total number of households}

The questionnaires were piloted in nearby villages targeting wetlands with similar characteristics (population characteristics and wetland use type) but not under study so as to ascertain relevance and reliability of the instruments. The field test was conducted with five household heads in each pilot study. This process enabled the researcher to use the feedback to amend the research instrument for clarity to the actual target group. English was used to structure the questions which were later translated to vernacular languages, that is, Shona and Ndebele for easy understanding. In line with covid-19 pandemic safety protocols, the researchers completed the questionnaire on behalf of the respondent interviewed to avoid contact and maintain physical and social distance.

Household heads provided information on their socio-demographic characteristics (age, marital status, household size), period of stay and distance from the wetland. Other aspects such as frequency of use and the reasons motivating wetland use were also covered in the questionnaire. Data on provisioning and cultural services derived from the wetlands was collected through a combination of open and closedended questions. Cultural services are non-tangible hence difficult to observe, therefore there was need to have an understanding from a human perspective.

The Headman in Driefontein was purposefully selected for the semi-structured interview to gather information on factors influencing wetland use, provisioning and cultural services derived from the wetlands. In the Intunjambili wetland, a Village head was selected to provide information on wetland use types. Two Agriculture Technical and Extension Services (AGRITEX) officers' resident in each wetland area was purposefully selected for semi-structured interviews to understand the trends of land uses. Two Environmental Management Agency (EMA) district officers were also purposively selected one from each district where the wetland under study is located. Semi-structured interviews employed open-ended questions that enabled probing of responses that needed clarification. Essential planning and logistical engagements were done in advance through liaison with respective informants over telephone conversations.

Four elderly people above the age of seventy (70), that is two from each wetland site were selected for the semi-structured interviews using the snowball sampling technique. These elderly people were selected 
based on duration of stay in the area since this attribute had a bearing on the wealth of knowledge possessed on wetland utilization patterns. Snowball sampling technique was used since elderly people are few and they could easily identify their contemporaries. Therefore, assistance to identify the first elderly person was sought from the Headman (Driefontein) and Village head (Intunjambili) who had knowledge of people in the area. Audio recording interviews gave an accurate summary of the interview as well as a reference point as they were repeated by the interviewer to have clarity on certain points during data analysis.

Data on rainfall trends obtained from Meteorological Services Department of Zimbabwe for the period 1989-2019 were subjected to Mann-Kendall statistical test using the XLSTAT software in Microsoft Office Excel. This was done to establish whether there was a significant change in annual rainfall total. Changes in annual rainfall totals influence frequency and wetland use type especially in communal areas where people depend on rain fed dryland crop cultivation. Qualitative data from the questionnaire, key informant interviews and direct observations were analyzed using the content analysis method whereby emerging themes, patterns and relationships were identified. In content analysis, categories or codes of words, themes and concepts within the texts were developed. Content analysis was used to develop categories or codes from qualitative data collected on factors influencing wetland utilization patterns and the nature of benefits derived from wetlands. Content analysis was also used to identify respondents' responses on patterns of vegetation, common wetland uses and Land Use Land Cover (LULC) changes. These were summarized and presented in tabular format. This was done to capture each respondent's view. Qualitative data on aspects such as cultural benefits which are non-tangible were summarized to support quantitative responses. Error bars were used to show if there are any significant differences in households' responses for various variables interrogated in the two wetlands. A Chi-square test was conducted to determine the association between household characteristics (gender, marital status, household size, education, number of years a family has stayed in the wetland) and wetland use type.

LULC changes as a result of human wetland use were detected using remote sensing image data sets for the period 1999 - 2019. This period was selected because of the socio-economic changes that occurred in the country which had a bearing on wetland utilization. For example, at the onset of the FTLRP in 2000, resettled people moved into the fringes of Driefontein wetland thereby converting natural habitats into crop cultivation. In the case of Intunjambili wetland, the FTLRP had potential to decongest the communal area. Landsat images from 1999 to 2009 were downloaded freely from the United States Geological Survey (USGS) at http://glovis.usgs.gov/ with a tile path of 170 row 73 and 171 row 74 (Table 2). Sentinel 2 images were obtained from Copernicus at http://glovis.usgs.gov/ with a tile path of 170 row 73 and 171 row 74 (Table 2).

\section{Table 2: Sources of images used in land use/cover change detection}

The images used were captured during the dry periods (August-October) when wetlands were distinct from other moisture devoid zones. Landsat images were used instead of the other available highresolution data sets such as RapidEye and SPOT for the first two decades because they were acquired 
freely. Priority was given to the magnitude of cloud cover on acquisition dates to ensure high degree of accuracy. This means that summer images were chosen because they are usually associated with low humidity and less cloud cover. Images acquired under these conditions have less distortions unlike those from winter with high cloud cover (Matsa et al. 2020). Since the images were downloaded in a compressed tar.gz format, WinZip software was used to extract data from.tar.gz format. In this study, data fusion incorporated Landsat data to fill gaps where Sentinel data was not available for given time frames and specific areas. Data from Sentinel satellites became available after 2017. Since this research focus on period 1999-2019, it was imperative to fuse the data sets.

Satellite imagery datasets obtained from Sentinel $2 \mathrm{MSI}$ and Landsat sensors were downloaded in TIFF picture format. Geometric and radiometric distortions that emanated from variations in sensor attributes and atmospheric conditions were corrected. For all images the registration was done using the Universal Transverse Mercator conformal (Co-ordinate system) projection employing ARC1950 as the Datum zone at $35 \mathrm{~S}$. Radiometric corrections were done through image enhancement. The image analysis option in ArcMap 10.5 was used to enhance brightness, contrast and transparency of images which was confirmed using the swipe ban option. Meta data was used to normalize spectral signatures of the earth's surface using the Raster calculator. The images were then converted to composite bands. The selected bands were imported into ArcMap 10.5 before data cleaning was done so as to remove the no data value region. In this manner, composite band image for the level 1 TIFF downloaded images was created through manipulation of the data analysis tool in the ArcMap 10.5 software.

In order to classify data into different categories the researchers had to understand the relationship between the data and the classes into which the data was classified (Matsa et al., 2020). Development of training sites was done based on prior knowledge of the study sites possessed by the researchers and baseline information obtained from Google Earth. The supervised classification method was used since it assigned pixels to a designated LULC type. In this research, training data derived from the visual interpretation of the colour composites achieved from the bands and the spectral signatures obtained from training samples was used as regions of interests (ROI). ArcMap 10.5 was used to perform supervised classification, with the image processing software being guided by the user to specify the land cover classes of interest. LULC classes were extracted from a multiband raster image by classifying the images according to their digital numbers (DNs).

Consequently, each pixel in the image was then assigned, based on its spectral signature to the class it mostly matched. It was important to choose training areas that covered the broad spectrum within each land cover to enable the software to accurately classify the rest of the image. The training set covered independent samples for each category. Land cover was grouped as cultivated + bare land, grassland and areas inundated with water. Cultivated and bare land were combined due to similarities in spectral responses. LULC changes were derived by comparing land cover images of the years 1999, 2009 and 2019 to ascertain rate of change. 
Post classification was done through accuracy assessment and computation of class statistics and changes in ArcMap 10.5. Ground truth regions of interest were used to assess the classified maps accuracy using the confusion matrix. The regions of interest for each classified image were exported and saved as shape-files which were then used to create maps in ArcGIS 10.5. The classification results for 1999, 2009 and 2019 were satisfactory as their accuracy was above $80 \%$. Calculation of the percentage area coverage of each class was conducted by adding fields in the ArcMap 10.5 attribute table of the classified images, showing number of pixels belonging to each class. For percentage calculation the attribute table was exported to Microsoft excel where area covered by each class was determined by multiplying the number of pixels belonging to that class by area of a single pixel $(30 \mathrm{~m}$ by $30 \mathrm{~m}$ spatial resolution of Landsat image and $10 \mathrm{~m}$ by $10 \mathrm{~m}$ spatial resolution of Sentinel 2 data).

\section{Results And Discussion}

\section{Dominant land use patterns in Driefontein and Intunjambili wetlands}

Questionnaire survey results revealed that both wetlands are used for different purposes (Figure 2). The majority of the households in Driefontein (86\%) and Intunjambili (75\%) indicated that there is no change in wetland utilization patterns over the past decade as horticultural activities remain the predominant activity. Horticulture was identified as the major land use pattern followed by livestock grazing (Figure 2). The elderly people in both Driefontein and Intunjambili indicated that horticultural activities are predominant due to moisture availability within the wetland. The Wetland Committee Chairperson in Driefontein wetland indicated that local people exchange horticultural products such as vegetables for maize in the surrounding rural communities. The same situation was observed by Marambanyika and Beckedahl (2016a), in a study conducted in Dufuya and Madigane where local people exchange vegetables for maize in nearby rural communities and or resettlement areas.

Wetland use for cattle grazing in Driefontein (52\%) has higher response frequencies by households than in Intunjambili (30\%). Wetland use for crop cultivation is high in Intunjambili (45\%), compared to Driefontein (23\%) (Figure 2). The Village head for Intunjambili highlighted that people turn to the wetland during the dry season for crop cultivation since it will be the only readily available source of moisture. The dominance of these activities confirms the notion that agriculture remains the backbone of rural livelihood strategies as the majority of the local people depend on agriculture for food and income. Given the importance of livestock in augmenting livelihood options through income generation, grazing pressure is likely to persist.

\section{Figure 2: Dominant wetland use pattern by households in wetlands}

Half of the respondents (50\%) in Intunjambili indicated that they fetch clean water for drinking from the wetland. This is different from Driefontein where a small proportion (14\%) indicated that they obtain water for drinking from the wetland. However, in the two wetland areas, the majority of the households have been using the wetland for more than one purpose (Figure 2). Chi-square test results show that there is an association between household head's socio-demographic characteristics $(p<0.05)$ and wetland 
use type. Results in Table 3 show that wetland use type varies with household head's gender $(p=0.028)$ and household size $(p=0.006)$. Thus, household head's gender and household size influences wetland use type.

\section{Table 3: Nature of association between household's demographic characteristics and wetland use type}

\section{Land use land cover changes in wetland areas between 1999 and 2019}

The majority of the households in Driefontein (86\%) and Intunjambili (75\%) indicated that LULC changes were experienced in the two wetlands under study. These LULC changes and their associated impacts on wetland components e.g., water and vegetation have reduced the spectrum of goods and services obtained from wetlands by local people. In 2009, grassland was the largest land cover in both Driefontein and Intunjambili wetlands (Table 4). Generally, the area under grassland has been increasing from 1999 to 2009. For the Driefontein wetland, grassland covered 414.7 ha in 2009 compared to 325.3 ha in 1999 , thus representing an increase of 27.5\%. In Intunjambili wetland grassland covered 27 ha in 2009 compared to 20 ha in 1999, which represents a significant increase of $45.1 \%$ over the same period (Table 4).

\section{Table 4: Land use land cover change in wetlands under study (measured in hectares and proportion of change in percentages) between 1999 and 2019}

The increase of cultivation area by 614.9\% in Driefontein between 1999 and 2009 (Table 4) was accompanied by loss of water cover as evidenced by a decline in the extent of areas inundated. The increase in cultivated area in Driefontein wetland between 1999 and 2009 was confirmed by over two thirds (70 \%) of the households. This was slightly different for Intunjambili wetland as cultivated + bare land decreased by 49\% between 1999 and 2009. In Driefontein households' practice either horticulture or cereal farming in wetlands which results in expansion of cultivated + bare land. Wetland use for agricultural activities is therefore a predominant activity, a situation also observed by Zsuffa et al. (2014). The increase in wetland cultivation may be attributed to the important role of agriculture towards livelihoods of poor vulnerable communities in semi-arid areas in Zimbabwe (Marambanyika and Beckedahl 2016a).

Human densities in the Driefontein wetland increased due to the FTLRP which commenced in 2000. This resettlement programme exposed the area to several land uses such as crop cultivation since the most of the households in the surrounding villages such as Welstead are poor (Fakarayi et al. 2015). Therefore, as population increases demand for wetland resources will be high for instance, gardening is likely to result in pressure in areas with poor granite sandy derived soils. Increase in cultivated + bare land in the Driefontein wetland was accompanied by loss of water cover as evidenced by a decline in the extent of areas covered by water. This can be attributed to water abstraction for several purposes such as cultivation and cattle grazing which resulted in wetland drying. This finding concurs that Marambanyika and Beckedahl (2016a) who observed that the drying of wetlands is linked to human activities such as cultivation. These activities result in establishment of artificial canals and drainage systems as 
households seek to improve their livelihoods. The increase of cultivated + bare land in Intunjambili wetland by $30 \%$ between 2009 and 2019 (Table 4), could be attributed increasing population which resulted in clearance of land as local people attempted to meet their food needs.

During an interview the Village head highlighted that significant reduction in the amount of rainfall received between 1999 and 2009 limited potential for crop cultivation. Mean annual precipitation data for the period between 1989 and 2019 show that the amount of rainfall received in the two areas has been fluctuating, although not statistically significant as shown by Mann-Kendall test results $(p<0.05)$. In Driefontein wetland, cultivated + bare land which covered 112.6 ha in 2009 increased to 168.5 ha in 2019 which accounts for an increase of $49.6 \%$. The Driefontein Headman revealed that the number of cattle owned by households increased from three in 2000 to six in 2019 which was reported to be resulting in increase in bare land. This is because cattle grazing results in alteration of vegetation and trampling which increases bare surfaces a position confirmed by Marambanyika and Beckhadhal (2016a). In the Intunjambili wetland, cultivated + bare land increased from 4.5 ha in 2009 to 5.3 ha in 2019 which signifies an increase of $30 \%$.

In 2009 water covered 221.5 ha in Driefontein wetland, compared to 410.9 ha in 1999 which shows a loss of $46.1 \%$ during the decade. Results in Table 4 show that between 2009 and 2019, water cover in the Driefontein wetland was reduced from 221.5 ha to 47.5 ha which represents a loss of $78.5 \%$. The EMA Officer for Chirumanzu district highlighted that Driefontein wetland experienced loss of water cover between 1999 and 2009 due to over abstraction for domestic use and crop cultivation. In the Intunjambili wetland, water which initially covered 1 ha in 1999 declined to 0.5 ha in 2009 which shows a loss of 50\% (Table 4). During an interview the Headman in Driefontein and Village head in Intunjambili wetland highlighted that LULC changes have been observed as areas which used to be inundated have become dry.

In Intunjambili, water dropped by $60 \%$ between 2009 and 2019 due to drying up of the areas covered by water as a result of a combination of climate change and human activities including brick moulding. Brick moulding was attributed to the need to expand settlements in response to the increasing population. This therefore resulted in clearance of grasslands and reduced water cover resulting in the disappearance of key aquatic species such as Kapenta and frogs which used to be found in the wetland. Land use changes and different human activities were, therefore, modifying the ecological functioning of the wetlands. A similar study by Murungweni (2013) on Monavale wetland in Harare revealed that cultivation and settlement establishment resulted in clearance of land hence loss of biodiversity, habitat and aesthetic value of wetlands. Therefore, LULC changes result in wetland deterioration especially in rural communities where dependency is very high a situation observed by Phethi and Gumbo (2019).

\section{Factors influencing wetland use}

The majority of the households in Intunjambili (90\%) indicated that the availability of water for domestic use and farming is the major factor influencing wetland use. This was different for Driefontein where market availability for horticultural products was the main reason for wetland use as indicated by $66 \%$ of 
the household heads (Figure 3). The Wetland Committee Chairperson at Driefontein indicated that households grow crops such as tomatoes, butternuts and potatoes which they sell to nearby urban centers such as Gweru and Masvingo. This finding concurs with Phethi and Gumbo (2019), who observed that in Makhitha wetland, availability of water has resulted in expansion of agricultural activities in order to meet the growing need for food

\section{Figure 3: Factors influencing wetland use type}

Questionnaire survey results also show that $29 \%$ and $40 \%$ of the households in Driefontein and Intunjambili cultivate in wetlands as a result of the decline in soil fertility in dry land areas (Figure 3). All interviewed elderly people in both Driefontein and Intunjambili indicated that over the past decade severe decline in soil fertility in dry land areas has been experienced. This has compelled local people to shift their attention to wetlands for survival. This implies that local communities turn to wetlands as the only safety net due to limited livelihood opportunities. This position was confirmed by Mandishona and Knight (2019) whose findings show that wetlands provide fertile soils and wet conditions which support crop cultivation throughout the year. In light of this assertion, local communities are bound to improve their food security during periods of droughts or in circumstances when their dry land crops fail.

\section{Provisioning services obtained from the wetlands}

Questionnaire survey results show that $63 \%$ of the households in Driefontein obtain water from the wetland to support horticultural activities (Figure 4). They indicated that various horticultural crops such as Daucus carota ssp. Sativa, Brassica oleracea are cultivated throughout the year. These findings are similar to those of Dehnhardt et al. (2019), who observed that wetlands have several services which contribute to human livelihoods through provision of food and opportunities for income generation. The majority of the households in Driefontein obtain water to support horticultural activities from the wetland. The wetland therefore generates most of the food and income for all the surveyed households. This may explain why Ward 20 where Driefontein wetland is located has a food poverty prevalence rate of $19 \%$ (Zimbabwe National Statistics Agency 2016). This is slightly lower than the average $21 \%$ for the whole of Chirumanzu district (Zimbabwe National Statistics Agency, 2016). Therefore, wetlands contribute to the attainment SDGs 1 (No poverty) and SDG 2 (Zero Hunger, achieve food security, improved nutrition and promote sustainable agriculture).

\section{Figure 4: Provisioning services derived by households from the Driefontein wetland}

Commenting on the provisioning services derived by local communities in Driefontein, the AGRITEX Officer pointed out that local households harvest approximately 1 tonne of maize for mealie meal and sale. Local communities take advantage of the presence of water from the wetland to support maize production. Every year local people manage to send maize to their relatives especially in nearby villages such as Palmfontein and Welstead because of drought prevalence. Maize is also sold to urban areas such as Masvingo and Gweru where the price of maize meal has been increasing. On the other hand, the EMA Officer for Chirumanzu highlighted that although wetlands provide readily available moisture, 
encroachment of plots into the wetland fringes is likely to reduce water cover hence reduced spectrum of goods and services. Wetland use for provision of wood for fuel is high in Driefontein, as highlighted by $46 \%$ who strongly agreed to this view point (Figure 4). This was different for Intunjambili as $50 \%$, disagreed that they collect fire wood from the wetland as they indicated that it was mainly dominated by grass (Figure 5).

This was slightly different in Intunjambili wetland where the majority of the households (60\%), indicated that they fetch clean water to use at home from the wetland (Figure 5). Sixty-six percent of the households in Driefontein agreed that the wetland is a source of water and pasture for livestock production. The same sentiments were also shared by $60 \%$ of the sampled households in Intunjambili who strongly agreed that wetlands provide water and pasture for livestock production, hence boosting the income options of the local communities as their livestock will fetch better market prices. The Driefontein Headman revealed that during drought years, almost all livestock, estimated to exceed 1000 cattle, in the area rely on the wetland for grazing and drinking water. This conforms with findings of Svotwa et al. (2008), where wetland use for cattle grazing in Mwaonazvawo has been increasing due to abundance of water and pastures. Wetland use for livestock grazing in Driefontein has been increasing over the past years due to frequent droughts that have been affecting pasture availability in dry land areas.

\section{Figure 5: Provisioning services derived by households from the Intunjambili wetland}

Questionnaire survey results show that $60 \%$ of the households in Driefontein wetland obtain construction materials from wetlands. About $50 \%$ of the households in Intunjambili wetland agreed that they collect wetland material such as Hypharrhenia femitia for thatching of houses (Figure 5). The Village head in Intunjambili indicated that local people collect Hypharrhenia femitia between June and July when they are not actively working on their fields. This was also observed by Adekola et al. (2008) and Phethi and Gumbo (2019) in studies conducted in wetlands of South Africa. About $17 \%$ of the households in Driefontein neither agreed nor disagreed (non-committal) on the collection of medicinal plants from the wetland. This was different in Intunjambili where $55 \%$ of the households agreed that the wetland is a source of medicinal plants (Figure 5). This can be attributed to the fact that many households in Driefontein did not want to show knowledge of herbs/ traditional medicines since it may be associated with witchcraft, a position confirmed by the Headman. This perception is largely linked to the adoption of western cultural practices that have adulterated the local tradition. Most of the local people either rely on clinics and or hospitals for medical assistance. Christianity has also eroded the significance of traditional beliefs including the use of traditional medicine.

\section{Cultural services realized from the wetlands}

Most households (43\%) in Driefontein strongly agreed that wetlands contribute to the aesthetic value of their local community (Figure 6). Households in Driefontein highlighted that the wetland has several features, which include the ever-green grassland and sections of unique bush-land surrounding the wetland. This natural environment has potential to lure people from foreign land due to its aesthetic quality as observed by Turpie et al. (2010). Contrary to this, few people (5\%) in Intunjambili realized that 
the wetland has aesthetic value. This was attributed to many burnt areas as a result of fire occurrences that are more frequent due to the presence of dry vegetation.

\section{Figure 6: Cultural services derived by households from the Driefontein wetland}

According to the EMA officer for Chirumanzu district the people travel from foreign countries to watch the globally threatened bird species such as the grey crowned crane (Balearica regulorum), secretary bird (Sagittarius serpentarius) and wattled crane (Bugeranus carunculatus), as well as view the natural mosaic presented by the natural state of the wetland. Therefore, the wetland presents an important opportunity for tourism. Studies by Murungweni (2013) and Mandishona and Knight (2019) considered wildlife viewing and bird viewing in wetlands as important recreational activities. More so, wetlands present opportunities for tours for academic incursions. This was confirmed by $45 \%$ of the households in Driefontein wetland. On the other hand, $50 \%$ of the respondents in Intunjambili indicated that the wetland is an important site for academic tours (Figure 7). Academic and research institutions such as the Birdlife Zimbabwe, Midlands State University and University of Zimbabwe have been visiting the Driefontein wetland for research and learning. The Village Head for Intunjambili, revealed that research institutions such as WaterNet partnered with the University of Zimbabwe to implement projects meant to understand the hydrological changes of wetlands. This implies that wetlands have educational value as researchers and students from various research institutions travel to explore on several wetland aspects as observed by Turpie et al. (2010), in wetlands of South Africa.

\section{Figure 7: Cultural services derived by households from the Intunjambili wetland}

In Driefontein, $40 \%$ of the households confirmed that they use the wetland for spiritual activities such as worshipping. It was observed that the people continue worshipping in the serene wetland area, where water is also available for baptism. Most households in Intunjambili (65\%) disagreed with the fact that wetlands provide opportunities for spiritual development (Figure 7). Therefore, wetland use for spiritual development is low in Intunjambili. This can be attributed to the fact that such practices were abandoned due to changes in culture and technology a situation also observed by Marambanyika and Beckedahl (2016a), in wetlands in semi-arid areas of Zimbabwe.

\section{Conclusion}

This article assessed drivers of wetland utilisation patterns and the current status of provisioning and cultural services in Driefontein and Intunjambili wetlands. The results of the study show that there has been no change in wetland use patterns over the past decades as horticulture remains the major land use pattern. Increase in cultivated + bare land was accompanied by loss of water cover as evidenced by a decline in the extent of areas covered by water. This implies that although agriculture is a backbone of the local communities it affects the integrity of wetland ecological components. Results demonstrate that households in Driefontein and Intunjambili use wetlands as a result of the decline in soil fertility in dryland areas which has left local people with no option. This in turn increases pressure on the wetland core area, which frustrates efforts aimed at protecting the wetlands. If no meaningful conservation 
measures are explored, the status of the wetlands will be compromised. Therefore, to ensure sustainable utilization of different wetlands there should be planned implementation of appropriate land uses depending on each wetland's hydrogeomorphic characteristics.

Wetlands provide a broad range of goods and services, which help to stabilize all dimensions of food security that is availability, access and utilisation, for communities adjacent to surveyed wetlands.

Overall, local communities obtain provisioning services such as clean water for domestic use, livestock pasture and moist conditions for crop farming. Instead of solely relying on wetlands for crop cultivation and cattle grazing, local people derive socio-cultural benefits. Change in socio-cultural beliefs has resulted in reduced significance of cultural services due to adoption of western culture. This has resulted in deterioration of goods and services derived from wetlands which frustrates wise use of wetlands. This suggests that human use activities should be controlled to ensure that wetlands continue to provide ecosystem services in the foreseeable future.

\section{Declarations}

The authors declare that this is their own work and has not been sent for publication elsewhere. The authors also declare no conflict of interests in this research.

\section{Funding}

This article is part of study that is being funded by the Wetland Monitoring and Assessment Services for Transboundary Basins of Southern Africa (WeMAST) Project funded under GMES and Africa programme.

\section{Conflicts of interest/Competing interests (include appropriate disclosures)}

The authors declare no conflict of interests.

\section{Ethics approval (include appropriate approvals or waivers)}

\section{Consent to participate (include appropriate statements)}

All households included in this study gave written informed consent to participate in this research. If the household head was not available, the eldest family member capable of making decisions participated in the survey.

\section{Consent for publication (include appropriate statements}

All households provided informed consent to publish the data contained within this article.

\section{Availability of data and material (data transparency)}

The datasets used and/or analysed during the current study are available from the corresponding author on reasonable request. All data produced from this study are provided in this manuscript. 


\section{Code availability (software application or custom code)}

Not applicable.

\section{Authors' contributions}

Conceptualization, Thomas Marambanyika (T.M.); methodology, T.M.; Tatenda Musasa (T.U.) Software, T.U.; validation, T.M. and TU.; formal analysis, T.M and T.U. investigation, T.M and T.U, data curation, T.U.; writing-original draft preparation, T.M. and T.U.; writing-review and editing, T.M and T.U. visualization, T.M. All authors have read and agreed to the published version of the manuscript.

\section{References}

Adekola O, Morardet S, De Groot R, Grelot F (2008) The economic and livelihood value of provisioning services of the Ga-Mampa wetland, South Africa. In 13th IWRA World Water Congress (pp. 24-p).

Bowling A (2005) Mode of questionnaire administration can have serious effects on data quality. $\mathrm{J}$ of Pub Health, 27(3), pp.281-291

Chiputwa B, Morardet S, Mano R (2006) 'Diversity of wetland-based livelihoods in Limpopo River basin'. WaterNet.

Chuma E, Masiyandima M, Finlayson M, McCartney M, Jogo W (2008) Guideline for sustainable wetland management and utilization: Key cornerstones. CPWF Project Report. Colombo, Sri Lanka: CGIAR Challenge Programme on Water and Food. https://hdl.handle.net/10568/21605

Creswell JW (2015) A concise introduction to mixed methods research. University of Nebraska: Lincoln, pp45-88.

Davidson NC, Fluet-Chouinard E, Finlayson CM (2018) Global extent and distribution of wetlands: trends and issues. Mar and Freshw Res, doi.org/10.1071/MF17019

Fakarayi T, Mashapa C, Gandiwa E, Kativu S (2015) Pattern of land-use and land cover changes in Driefontein Grassland Important Bird Area, Zimbabwe. J Trop Cons Sci, 8(1): 274-283

Finlayson CM, Pollard S (2009) 'A framework for undertaking wetland inventory assessment and monitoring in the Limpopo Basin Southern Africa'.

Government of Zimbabwe (GoZ) (2015) Fifth National Report to the Convention on Biological Diversity. Ministry of Environment and Water and Climate, Harare

Hove C, Chapungu L (2013) Human perceptions on degradation of wetland ecosystems: The case of Magwenzi Wetland in Chivi District; Zimbabwe J Geo and Ear Sci, 1(1), pp.013-022. 
Kotze DC (2011) The application of a framework for assessing ecological condition and sustainability of use to three wetlands in Malawi. Wetlands Ecology and Management, 19 (6):507-520

Madebwe V, Madebwe C (2005) 'An exploratory analysis of the social, economic and environmental impacts on wetlands: The Case of Shurugwi District, Midlands Province, Zimbabwe', J Appl Sci Res, 1(2), pp. 228-233.

Mandishona E, Knight J (2019) Users' perceptions and understanding of two urban wetlands in Harare, Zimbabwe. S Afr Geogr J.;101(3):326-348

Marambanyika T, Beckedahl H (2016a) Wetland utilisation patterns in semi-arid communal areas of Zimbabwe between 1985 and 2013 and the associated benefits to ivelihoods of the surrounding communities, Trans R Soc S Afr. doi:10.1080/0035919X.2016.1152520

Marambanyika T, Beckedahl H (2016b) Institutional arrangements governing wetland utilization and conservation in communal areas of Zimbabwe. Rev of Soci Sci 2(1): 1-17

Marambanyika T, Beckedahl H, Ngetar NS, Dube T (2016) 'Assessing the environmental sustainability of cultivation systems in wetlands using the WETHealth framework in Zimbabwe, Phys Geog, DOI:10.1080/02723646.2016.1251751

Matsa M, Mupepi O, Musasa T, Defe R (2020) A GIS and remote sensing aided assessment of land use/cover changes in resettlement areas; A case of ward 32 of Mazowe district, Zimbabwe. J Env Manag, 276, p.111312.

Mazvimavi D (2010) Investigating changes over time of annual rainfall in Zimbabwe, J Hyd and Ear Sys Sci 14(12): 2671-2679

Mbereko A, Mukamuri BB, Chimbari M J (2015) Exclusion and contests over wetlands used for farming in Zimbabwe: A case study of broad-ridge and broad-furrow tillage system on Zungwi Vlei. J of Pol Ecol, 21: 322-338

McCartney M, Morardet S, Rebelo LM, Finlayson CM, Masiyandima M (2011) A study of wetland hydrology and ecosystem service provision: GaMampa wetland, South Africa. Hydrol Sci, 56(8), pp.14521466.

Millennium Ecosystem Assessment (2005) Ecosystems and human well-being. Island press Washington, DC

Msipa M (2009) Land use changes between 1972 and 2008 and current water quality of wetlands in Harare, Zimbabwe. Dissertation, University of Zimbabwe

Mtambanengwe F (2006) 'An ecological monitoring framework for Intunjambili wetland in Zimbabwe'. University of Zimbabwe, Harare. 
Mugandani R, Wuta M, Makarau A, Chipindu B (2012) Reclassification of agro-ecological regions of Zimbabwe in conformity with climate variability and change. J Afr Crop Sci 20(2): 361-369

Murungweni FM (2013) Effect of land use change on quality of urban wetlands: a case of Monavale wetland in Harare. Geoinfor Geostat: An Overview. http://dx.doi.org/10.4172/2327-4581.S1-015

Musasa T, Marambanyika T (2020) Threats to sustainable utilization of wetland resources in Zimbabwe: a review. Wetl Ecol and Manag, DOI 10.1007/s11273-020-09732-1 28: (4)681-696

Ndhlovu N (2012) 'A Preliminary Assessment of the Wetland Biological Integrity in Relation to Land Use: A Case of the Intunjambili Wetland, Matobo District, Zimbabwe. University of Zimbabwe, Harare

Ndiweni NJ, Gwate O (2013) Public perceptions of climate variability risks on wetland management: A case of ward 15 of Matobo North District, Zimbabwe. Asian J Soci Sci Humanit 3(1): 28-38

Ongoro W (2017) 'Assessing the Effectiveness of National Wetland Adaptation and Management Frameworks in Kenya; The case of Nyando Wetland Ecosystem

Phethi MD, Gumbo JR (2019) Assessment of impact of land use change on the wetland in Makhitha village, Limpopo province, South Africa. Jamba 11(2), doi: 10.4102/jamba. v11i2.693

Ramsar Convention Secretariat (2018) Global Wetland Outlook: State of the world's wetlands and their services to people. Gland: Ramsar Convention Secretariat.

Rebelo LM, McCartney M P, Finlayson CM (2010) Wetlands of Sub-Saharan Africa: distribution and contribution of agriculture to livelihoods. Wetl Ecol and Manag, 18(5):557-572

Russi D, ten Brink P, Farmer A, Badura T, Coates D, Förster J, Kumar R, Davidson N, (2013) The economics of ecosystems and biodiversity for water and wetlands. London: IEEP.

Sakané N, Alvarez M, Becker M, Böhme B, Handa C, Kamiri HW, Van Wijk MT (2011) Classification, characterisation, and use of small wetlands in East Africa. Wetlands 31:1103-1116.

Svotwa E, Manyanhaire IO, Makombe P (2008) 'Sustainable gardening on wetlands in the communal lands of Zimbabwe', Elec J Environ, Agri and Food Chem, 7(3), pp. 2754-2760.

Turpie J, Lannas K, Scovronick N, Louw W (2010) 'Wetland valuation Vol I-Wetland ecosystem services and their valuation: a review of current understanding and practice.', WRC Report. Water Research Commission, (440/09).

Zimbabwe National Geo-Spatial and Space Agency (2020) Zimbabwe Agro-Ecological Zones 2020: ZINGSA Geo-Spatial and Earth Observation Department, Mt Pleasant, Harare.

Zimbabwe National Statistical Agency (2013) Zimbabwe Population Census, 2012 Zimbabwe Main Report. 
Zinhiva H, Chikodzi D, Mutowo G, Ndhlovu S, Mazambara P (2014) 'The Implications for loss and degradation of wetland ecosystems on sustainable rural livelihoods: Case of Chingombe community, Zimbabwe', Greener J Environ Manag and Pub Saf 3(2), pp. 43-52.

Zsuffa I, Van Dam AA, Kaggwa RC, Namaalwa S, Mahieu M, Cools J, Johnston (2014) 'Towards decision support-based integrated management planning of papyrus wetlands: a case study from Uganda', Wetl Ecol and Manag Springer, 22 (2), pp. 199-213.

\section{Figures}

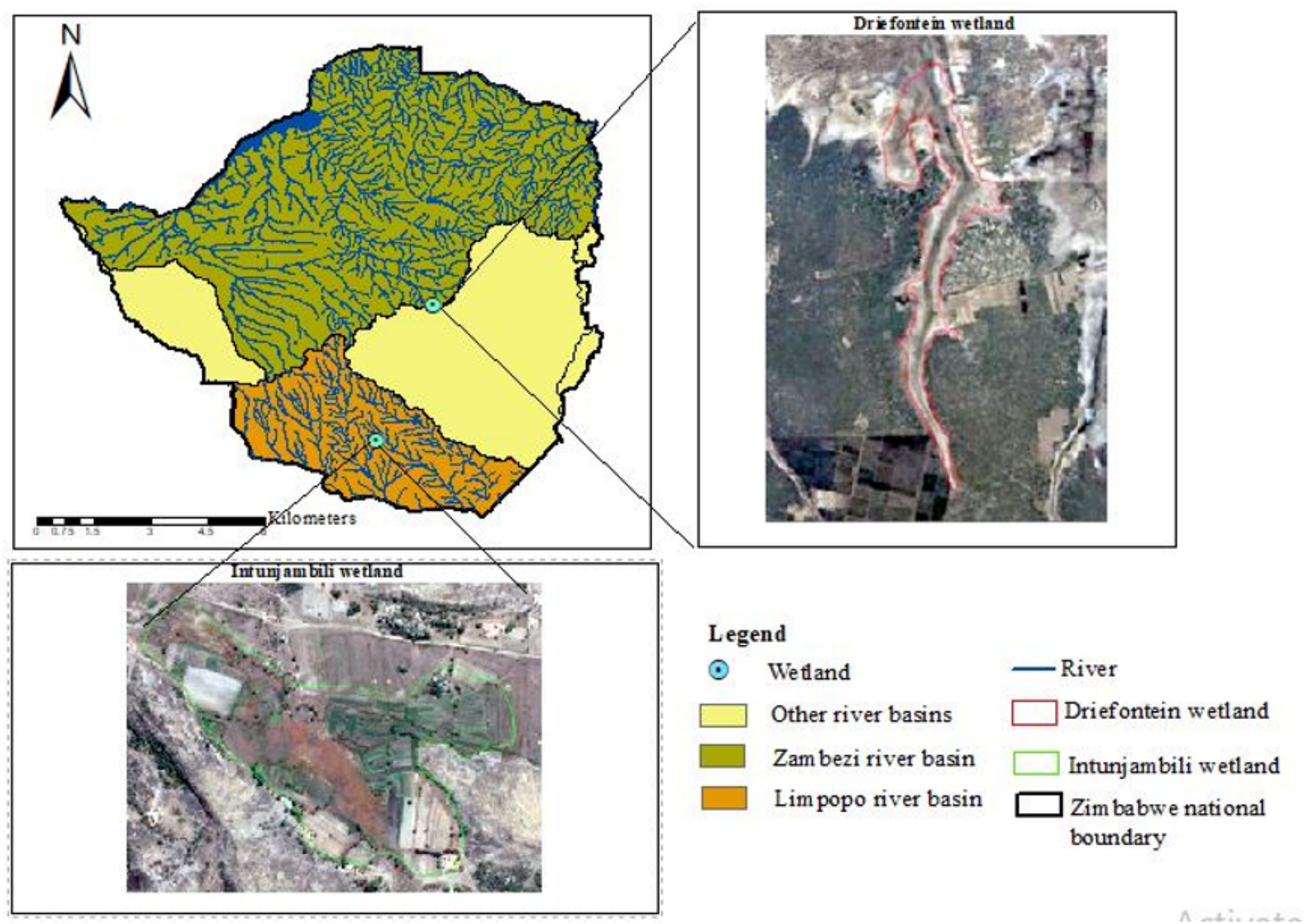

\section{Figure 1}

Map showing the location of the wetlands studied 


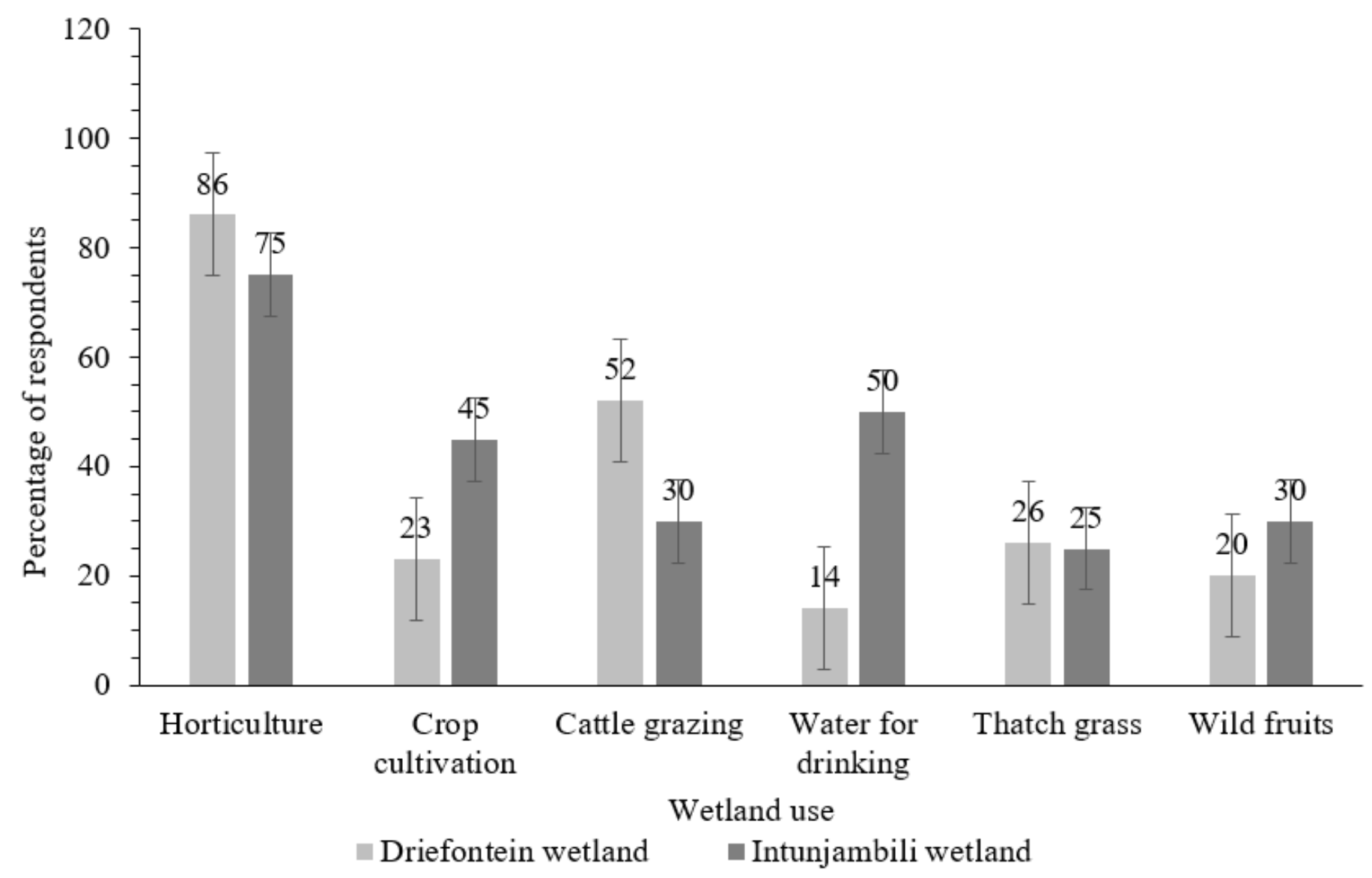

Figure 2

Dominant wetland use pattern by households in wetlands 


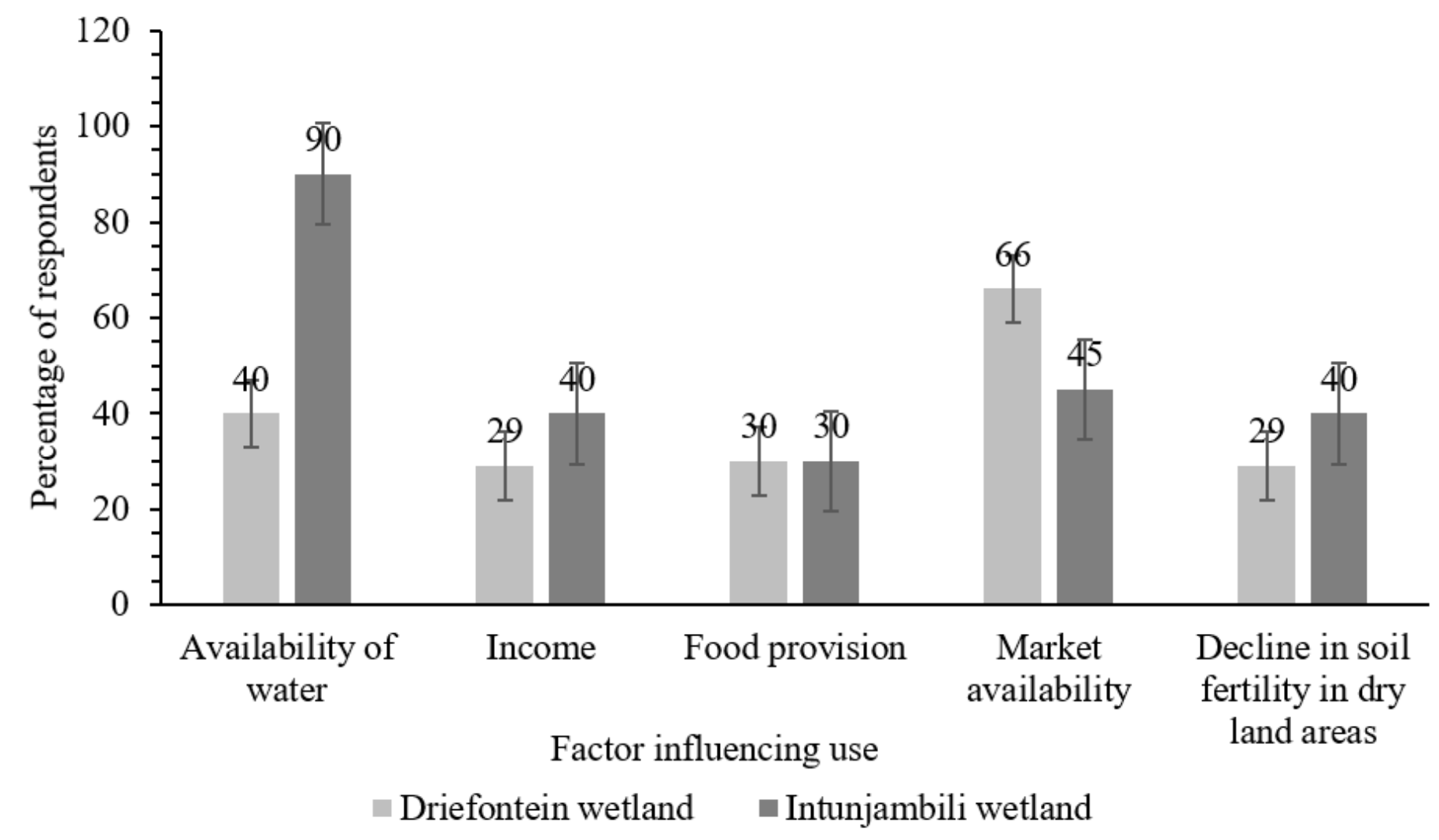

Figure 3

Factors influencing wetland use type 


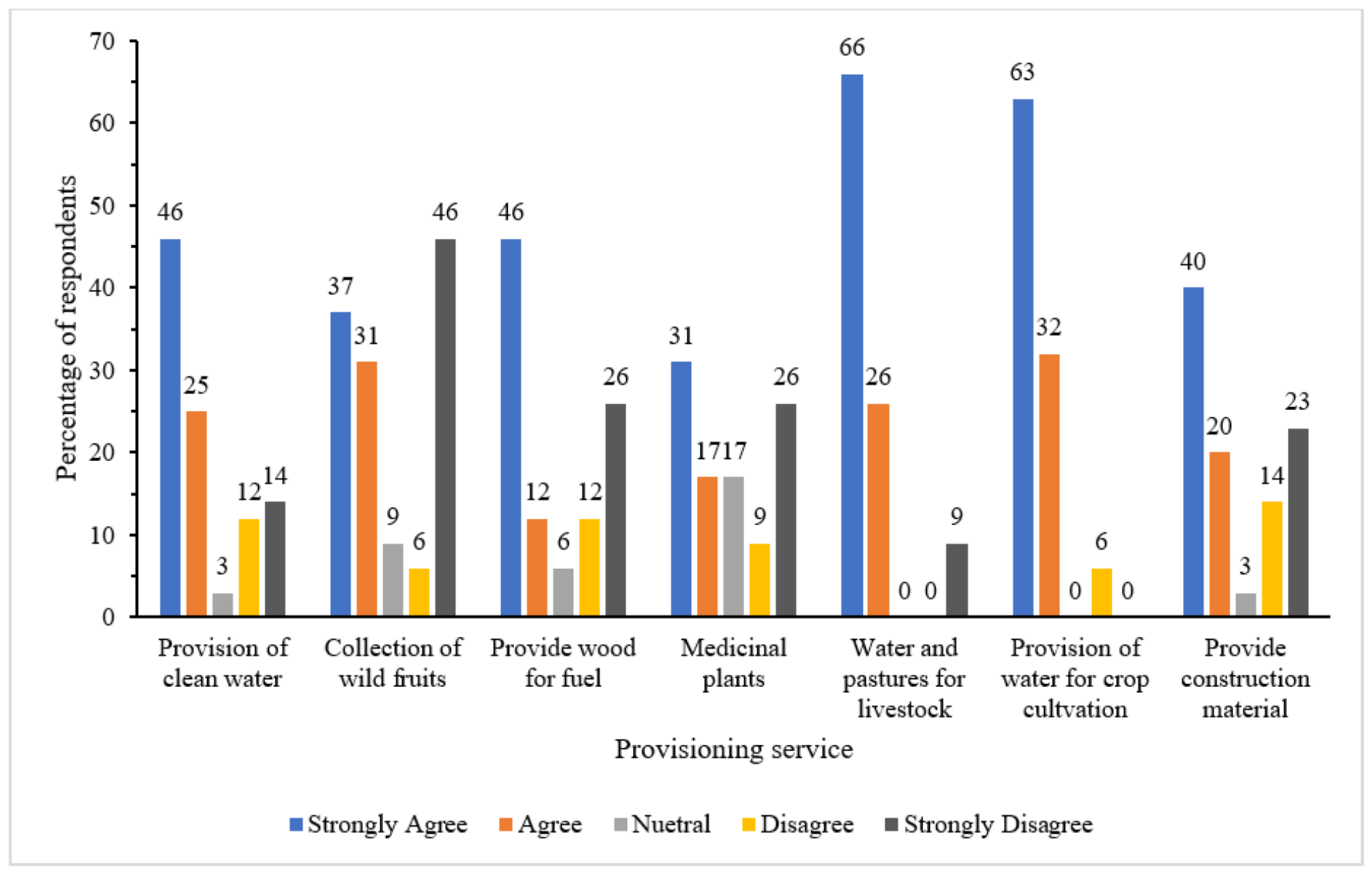

Figure 4

Provisioning services derived by households from the Driefontein wetland 


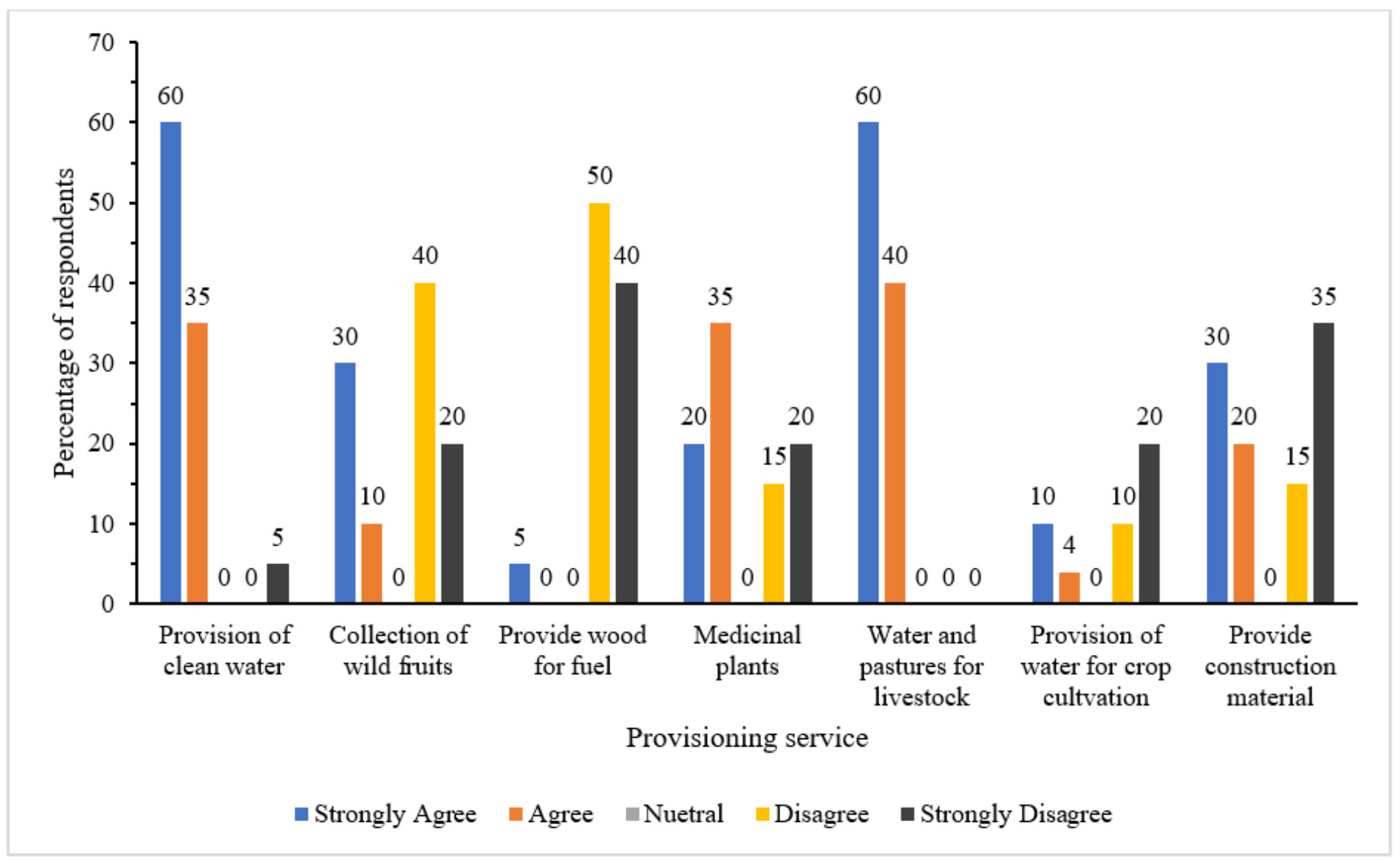

Figure 5

Provisioning services derived by households from the Intunjambili wetland 


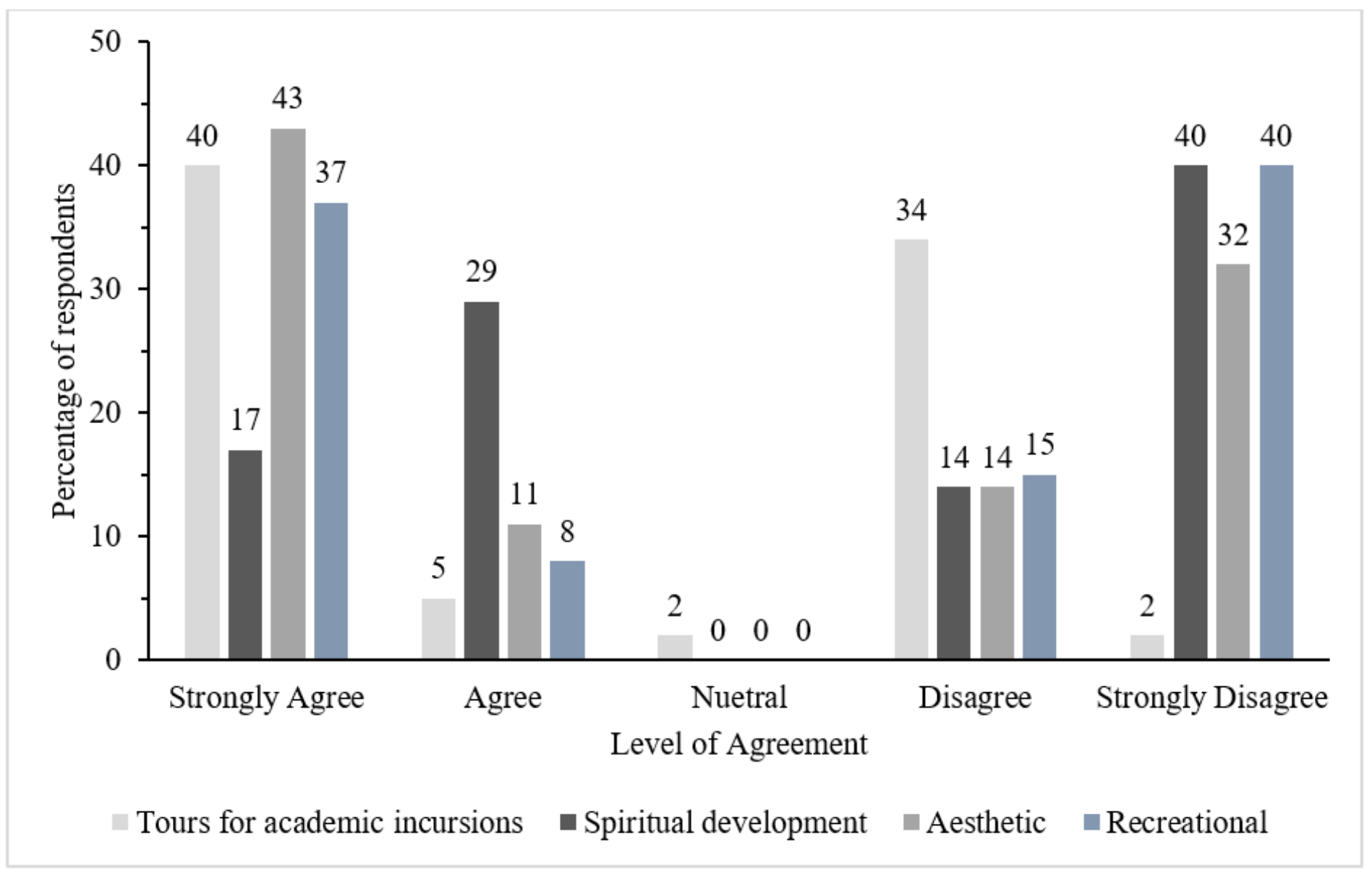

Figure 6

Cultural services derived by households from the Driefontein wetland 


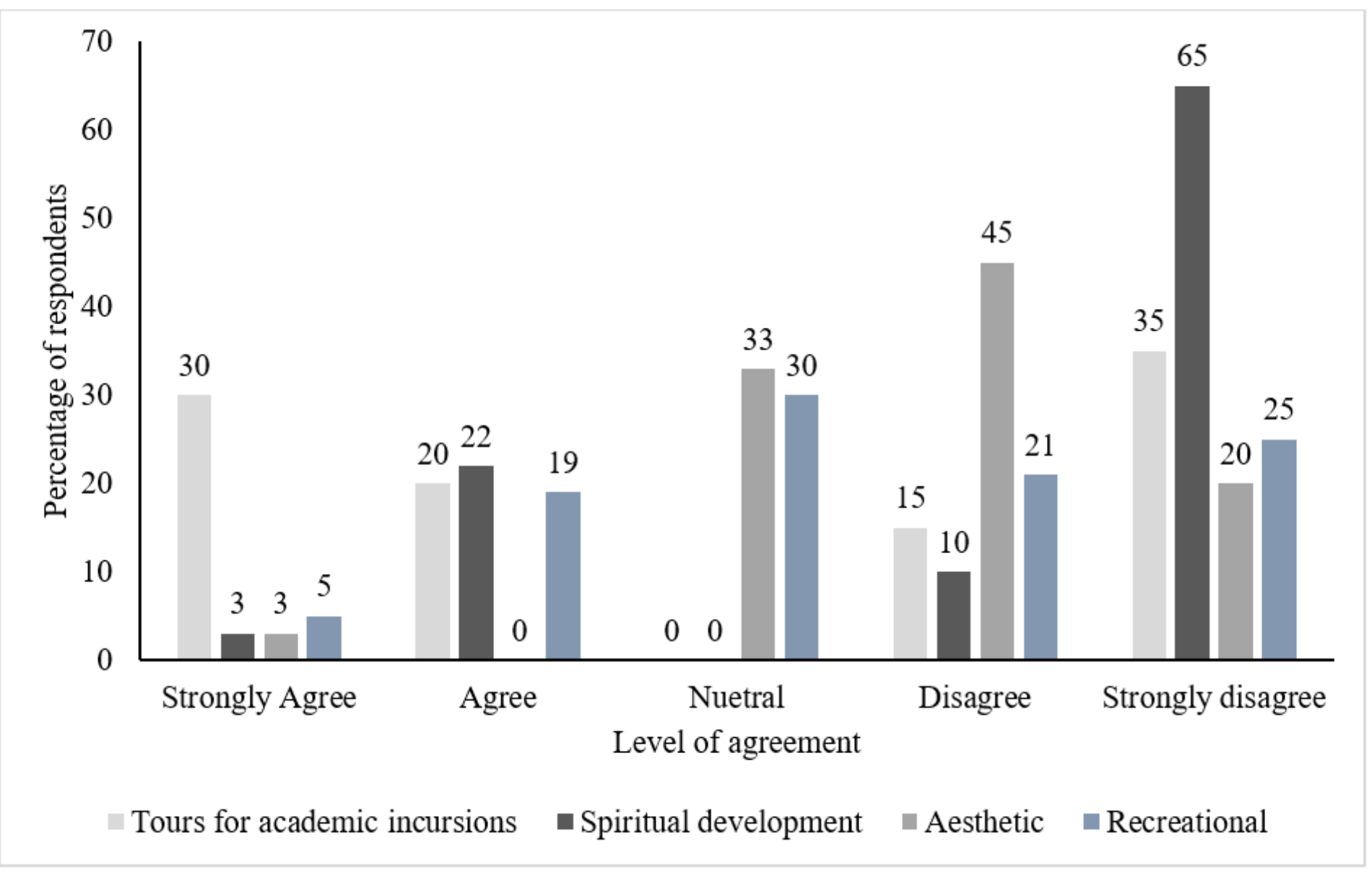

Figure 7

Cultural services derived by households from the Intunjambili wetland 